\section{Mechanical activation of power station fly ash by grinding - A review}

GÁBOR MUCSI - University of Miskolc - ejtmucsi@uni-miskolc.hu

Érkezett: 2016. 01. 10. " Received: 10. 01. 2016. " http://dx.doi.org/10.14382/epitoanyag-jsbcm.2016.10

\begin{abstract}
Power station fly ash has good application possibilities mainly in the construction industry, nevertheless, significant amount is landfilled due to their relatively low reactivity and heterogeneity. Hydraulic properties of fly ashes can be tailored by mechanical activation achieving a higher added value product, for example supplementary cementing materials (SCMs). The improved properties are higher specific surface area and desired particle size distribution (containing submicron size particles) as well as higher amount of reactive components that can be optimized by grinding. The objective of this paper is to investigate the effect of mechanical activation of fly ash by grinding on physico-chemical and minerological properties. It can be established that there are numerous techniques for mechanical activation of fly ash, e.g. planetary ball mill, vibratory mill or stirred media mill. On the other hand, most of the results reported in the literature are focusing on material related investigations, but beside this, from energetic point of view the process related evaluation has even higher importance.

Keywords: mechanical activation, grinding, power station fly ash, reactivity, energy efficiency.
\end{abstract}

Gábor MUCSI Associate Professor and Deputy Dean at the University of Miskolc, Faculty of Earth Science and Engineering, Institute of Raw Material Preparation and Environmental Processing. His main fields in education and research are mechanical processes - comminution, especially fine grinding, mechanical activation - and utilization of industrial by-products and waste materials. He has more than 100 publications.

\section{Introduction}

Sustainable raw material management requires the utilization of industrial by-products and waste materials as secondary raw materials. Typical examples are the silicate or aluminosilicate based raw materials, like power station fly ash, mining waste materials and metallurgical slags, which are generated in enormously large amounts worldwide [1], and therefore they are available at a relatively low price. However, the quality of these kinds of materials is very heterogeneous. Therefore, it is necessary to control their characteristics, to improve the performance of the final product which can be conducted by various ways, i. e. mechanical, thermal or chemical methods. The main application field of the above materials is the construction industry.

The goal of this paper is to present a brief description of mechanical activation as a tool for optimizing the quality of secondary raw materials focusing on the preparation of fly ash. The paper deals with the effect of mechanical activation on the physical, physicochemical and mineralogical properties of fly ash. The paper summarizes the application of mechanically activated fly ash reported recently as raw material for geopolymer and hydraulic binder.

\section{Mechanical activation}

Smekal [2] defined the term mechanical activation as processes affected by mechanical energy, which increase the chemical reactivity of the system without altering chemical composition. However, there are several forms of mechanical activation (MA) and the following techniques can be distinguished [3]: a) mechanical dispersion (size reduction) where the higher reactivity is the result of the increased specific surface area, b) surface activation where mechano-chemical reactions take place on the particle surface, and c) mechanochemical (structural) activation where inner parts of the particle are transformed to other structure as well.
The primary effect of mechanical activation (MA) is the comminution of particles, which results in changes in a great number of physicochemical properties of a particular system. During mechanical activation, the structure of a material usually becomes disordered and the generation of defects or other metastable forms can be observed [4]. It has been reported that the application of high energy mills (e.g. planetary mills and vibratory mills) allow the change of the structure and surface properties of solid materials $[5,6]$.

Grinding is defined as work expended against the bonding energy of solid materials (crystal), where bonding energy is equal to theoretical energy demand to remove the atoms or ions from each other to infinite distance. Therefore, the bonding energy can be calculated as follows [3]:

$E=n_{i} e_{i}+n_{S} e_{S}=\left(n-n_{S}\right) e_{i}+n_{S} e_{S}=n e_{i}-n_{S}\left(e_{i}-e_{S}\right)$

where $n e_{i}=E_{U}$ is the bonding energy in the non-dispersed system (internal term, lattice energy) and $n_{S}\left(e_{i}-e_{S}\right)=E_{S}$ is the surface energy (surface term). The $n$ is the number of atoms (internal or surface) and the e is the bonding energy of atoms (internal or surface).

On the other hand, besides grinding, reactivity of the solids can be tailored by further mechanical methods such as classification $[7,8]$ by air classifiers or separation by physical properties using various separators (magnetic, electrostatic etc.) The drawback of these technologies is that only a certain part of the total mass is utilized and the rest is landfilled. Furthermore, the pozzolanic activity is not improved [9]. A possible option might be the combined application of grinding and classification as a closed circuit by classification of the fine particles, then mechanical activation of the coarse fraction by grinding. There are other activation techniques to tailor reactivity of fly ash like thermal, chemical activation or the combination of the aforementioned methods [10].

In general, mechanical activation affects the dispersity properties of the materials, in terms of particle size distribution 
(PSD) and specific surface area (SSA), as well as particle shape, morphology and mineralogical composition. These characteristics define together the reactivity of the product.

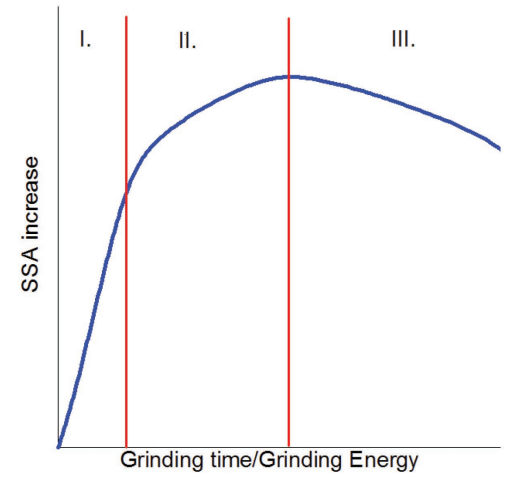

Fig. 1. Schematic diagram of the stages of grinding, based on [11]

1. ábra Azőrlés fokozatainak sematikus ábrája, [11] alapján

Fig. 1 shows the schematic diagram of grinding kinetics, i.e. effect of grinding time (or grinding energy) on the increase of specific surface area of the ground material. Three main stages can be distinguished [11]:

I. Rittinger stage where considerable increase of SSA appears, comminution takes place relatively quickly due to the high number of material defects (dislocations, pores, inclusions, lattice defects); in this case grinding energy is proportional to the produced increase in SSA.

II. Aggregation stage where the intensity of size reduction is moderated, adhesion of particles to the surface of the grinding media, to the lining, or to each other begins. In this stage the flattering of the curve shows that the energy efficiency decreases. The energy is used for deformation of the adhering layer of the particles.

III. Agglomeration stage which means apparent coarsening of the material after a certain maximum fineness. Crystal structure and mechano-chemical changes take place.

Most of the silicate and alumino-silicate based materials (e.g. cement clinker, quartz, fly ash, slags) are susceptible to aggregation and agglomeration. Therefore, it is crucial to eliminate the adhesion forces between particles which can be realized by various surface-active materials, by dosing so called grinding aids $[3,39]$.

\section{Materials}

Coal Combustion Products (CCP) or Coal Utilization Byproducts (CUB), including fly ash (FA), are industrial by-products generated in enormously high quantity worldwide, almost 800 million $t / y$ [1], as a result of the coal based energy production which represents significant contribution to the electricity production worldwide, for example: $80 \%$ in China, $47 \%$ in Australia, $42 \%$ in United Sates of America, almost 30\% in Europe [12].

Fly ash is a finely dispersed granulated material with spherical shape of particles and approx. 100-150 $\mu \mathrm{m}$ maximum particle size, generated by burning of coal in the boiler of power stations and collected by mechanical separators (electrostatic and bag filters). The main chemical components are $\mathrm{SiO}_{2}$, $\mathrm{Al}_{2} \mathrm{O}_{3}, \mathrm{Fe}_{2} \mathrm{O}_{3}$ and $\mathrm{CaO}$ beside minor components such as $\mathrm{Na}_{2} \mathrm{O}$,
$\mathrm{K}_{2} \mathrm{O}, \mathrm{TiO}_{2}, \mathrm{MgO}, \ldots$ [17]. Based on the oxide composition, class $\mathrm{C}$ and class $\mathrm{F}$ fly ash can be distinguished, latter one has lower $\mathrm{CaO}$ and higher $\mathrm{SiO}_{2}$ content than the previous one [23]. Their characteristic mineralogical phases are quartz, mullite, lime and hematite $[13,14]$. Beside these minerals fly ash usually contains amorphous constituents as well which are responsible mainly for the reactivity.

The relatively high amorphous content is a required parameter from utilization point of view. However, it is well known that significant amount (about 50\%) of the by-products is landfilled [1], causing a serious environmental risk [44]. In this way the composition of these materials change due to weathering conditions resulted in a lower reactivity. Muluken et al [15] investigated the chemical, mineralogical and geochemical properties of landfilled fly ash and revealed the formation of secondary minerals (calcite and ettringite) mainly due to hydration, carbonation and pozzolanic reactions. Kusnierova et al [16] found devitrification in case of previously landfilled fly ash, i.e. the reduced in the ratio of glassy phase: amorphous content of initial fresh fly ash reduced by $20 \%$ after 5 years, and by additional $12 \%$ after 20 years.

On the other hand, the reactivity of these by-products can be controlled by mechanical activation (grinding) [17-19].

\section{Methods}

Since mechanical activation alters the physicochemical properties (particle size distribution, specific surface area, surface energy, phase composition of powders), the exact determination of these properties is of great importance. Concerning the particle size distribution (PSD), it can be determined by various ways: dry or wet sieving, sedimentation or laser scattering methods. The most widely used apparatus is the laser particle size analyzer (LPSA) which is carried out generally in distilled water or in alcohol media using dispersing agent to desagglomerate secondary particles.

Specific surface area (SSA) of solids can be referred as either outer surface or total surface, which can be determined by Blaine or BET (Brumauer-Emett-Teller) methods, respectively. The Blaine method is based on air permeability of material bed, and it is widely used in the cement industry [45]. The BET method represents the inner pores (micro- and mezo pores) of the particles as well, based on gas adsorption on the surface of the investigated solid material. The difference between the value of Blaine and BET surface might be as high as several magnitudes, i. e. a Hungarian power station fly ash (from Tiszaújváros) was characterized with $2724 \mathrm{~cm}^{2} / \mathrm{g}$ Blaine and $82000 \mathrm{~cm}^{2} / \mathrm{g}$ BET specific surface area [20].

Material structure can be identified by fourier transform infrared spectroscopy (FTIR) in transmission or reflectance mode (ATR). The X-ray diffraction (XRD) technique is used for mineral phase analysis. Morphology and particle shape of the ground material can be investigated by optical or scanning electron microscopy (SEM) or by transmission electron microscopy (TEM).

Equipment of mechanical activation might be traditional tumbling ball mill or high energy density mill (HEM) like planetary ball mill, vibratory mill or stirred media mill. 


\section{Mechanical activation of FA}

Based on the results of mechanical activation of fly ash in stirred media mill, Molnár et al [21] reached submicron fine fly ash product at $7 \mathrm{~m} / \mathrm{s}$ circumferential speed (stress intensity $\mathrm{SI}=2.14 \times 10^{-4} \mathrm{Nm}$ ) for 10 minutes grinding time $(\mathrm{SSA}=7.76$ $\left.\mathrm{m}^{2} / \mathrm{g}, \mathrm{x}_{50}=0.8 \mu \mathrm{m} ; \mathrm{x}_{80}=1.98 \mu \mathrm{m}\right)$. The amount of mullite $2: 1$ decreased, parallel to mullite $3: 2$ increased at 5 and $7 \mathrm{~m} / \mathrm{s}$ as function of grinding energy. Increasing the grinding time has increased X-ray amorphicity. A crystalline particle is coated with an amorphous layer (5-15 nm thickness) is shown in Fig. 2 that is expected to be generated by the mechanical activation process.

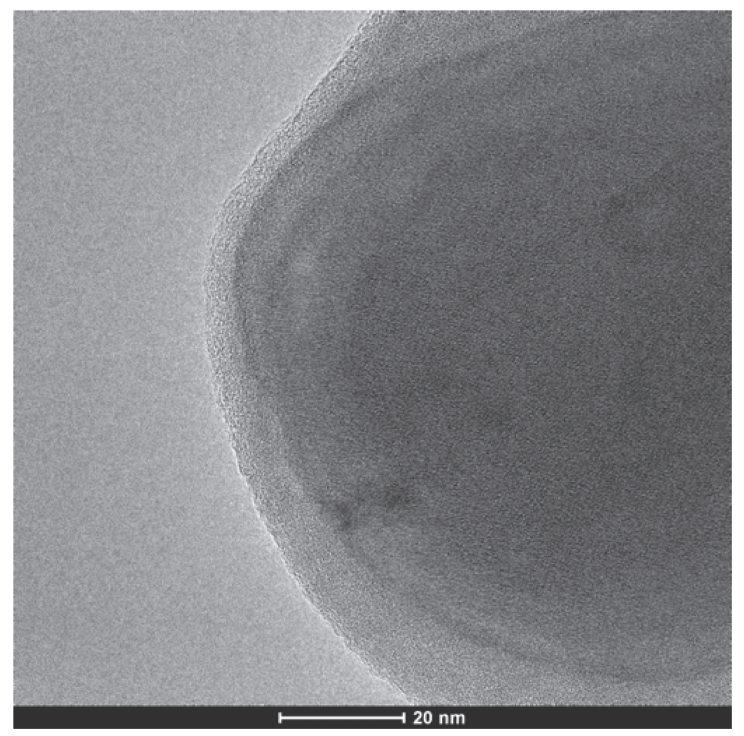

Fig. 2. TEM image of MA fly ash particle after 60 min grinding time [21]

2. ábra Mechanikailag aktivált pernye szemcse TEM felvétele 60 perces örlést követöen [21]

Mucsi et al [22] evaluated the variation of particle density of raw and ground fly ash. Significant increase in the particle density was observed as function of grinding time. Namely, from the initial value of $1.94 \mathrm{~g} / \mathrm{cm}^{3}$ the density increased to $2.26 \mathrm{~g} / \mathrm{cm}^{3}$ after grinding time of 20 minutes in a tumbling ball mill. It can be explained by the porous structure of fly ash. A plateau in the particle density-grinding time curve is reached after grinding time of 20 minutes and only slight increase was detected afterwards - in spite of that the material fineness is remarkably changed further. It can be found that the fly ash reached its material density $\left(2.27 \mathrm{~g} / \mathrm{cm}^{3}\right)$.

Terzic et al [24] realized that the mechanical activation in vibratory mill promoted the amorphization of the fly ash product, induced the changes in its microstructure, reduced the size of the fly ash particles and increased the specific surface area, which are together prerequisites for increasing the reactivity of the material. Optimal residence time of MA was 20 minutes.

Paul et al [25] carried out high energy ball milling on class F fly ash. The particle surface of the nanostructured fly ash is more uneven and rough, the shape is irregular, as compared to fresh fly ash which has particles mostly spherical in shape. They achieved significant reduction in crystallinity (from 35\% down to $16 \%$ ) in high energy milled fly ash after $60 \mathrm{~h}$ (!) residence time by the destruction of quartz and hematite crystals. As a result, the median particle size was reduced from $60 \mu \mathrm{m}$ to $148 \mathrm{~nm}$.

Fu et al [26] investigated the physico-chemical characteristics of mechanically-treated circulating fluidized bed combustion (CFBC) fly ash. The water requirement decreased with prolonged grinding time, and slightly increased during the last stage of grinding. The $\mathrm{pH}$ of ground CFBC fly ash is greater than that of the original fly ash, indicating that ground samples react more rapidly with water. The intensity of the crystalline phases of ground CFBC fly ash decreases, which means that ground fly ash has higher reactivity than that of the original fly ash.

Sharma et al [27] studied the variation in silica composition as function of milling time which indicates that the silica percentage is increased marginally after milling for 5 to 15hours, and the specific surface area (BET) is increased from 9 to $17 \mathrm{~m}^{2} / \mathrm{g}$. The increase in $\mathrm{SiO}_{2}$ content was in agreement with the results of $[25,38]$ which reasons are not explained in details in their studies. The crystallite size is reduced from the original $33 \mathrm{~nm}$ to $21 \mathrm{~nm}$ as milling time was increase up to 15 hours [27]. The FTIR spectra showed broad band between 3400-3000 $\mathrm{cm}^{-1}$, was attributed to surface-OH groups of $\mathrm{Si}-\mathrm{OH}$ and adsorbed water molecules on the surface. The broadness after ball milling for 15 hours is an evidence for the breaking down of the quartz structure and formation of $\mathrm{Si}-\mathrm{OH}$ groups [28]. The FTIR studies clearly showed changes in the broadening of IR peaks corresponding to Si-O-Si asymmetric stretching vibrations (1101 to $1090 \mathrm{~cm}^{-1}$ ) indicating structural rearrangement during mechanical treatment for 15 hours.

FA can be transformed; the initial FA turns to a nanostructured material through high energy planetary ball milling for 30 hours as reported by Rao et al [29]. The crystallite size was reduced from $92 \mathrm{~nm}$ to $29 \mathrm{~nm}$ and the percentage of crystallinity reduced from $63 \%$ to $38 \%$. The original spherical shape changed to irregular after 30 hours residence time and the surface morphology was rough.

Sharma et al [30] established that mechanical activation in high energy planetary ball mill results in increase in silica percentage, amorphous nature, specific surface area and surface roughness. Furthermore, thermal activation results changes in phase mineralogy, removal of amorphous carbon and enhances the silica amount. The intensity of IR peaks corresponding to $\mathrm{Si}-\mathrm{O}-\mathrm{Si}$ symmetric stretching vibrations $\left(697 \mathrm{~cm}^{-1}\right)$ and T-O$\mathrm{Si}(\mathrm{T}=\mathrm{Si}, \mathrm{Al})$ asymmetric stretching vibrations $\left(1161 \mathrm{~cm}^{-1}\right)$ after milling that indicates structural rearrangement during mechanical activation.

In the work of Patil and Anandhan [31] a class-F fly ash was subjected to planetary ball milling induced mechano-chemical activation aided by a surfactant. The nanostructured fly ash was characterized by dynamic light scattering, BET surface area analysis, X-ray diffraction, FTIR spectroscopy, scanning electron microscopy, field emission scanning electron microscopy and transmission electron microscopy. The ballto-powder weight ratio and the surfactant type are the major influencing factors on lower crystallite size and average particle size and higher specific surface area. The surface modification of fly ash was confirmed by FTIR spectroscopy. 


\section{Applications of mechanically activated FA}

The mechanically activated fly ash can be utilized mainly as raw material for hydraulic binder (Portland cement) or for geopolymer concerning mass production worldwide. Fly ash utilization in Portland cement has a very detailed literature from the beginning of the last century [32], however, geopolymers just come to the front a few decades ago [33].

Somna et al [34] studied $\mathrm{NaOH}$-activated ground fly ash geopolymers, cured at room temperature. Ground fly ash with a median particle size of $10.5 \mu \mathrm{m}$, was used as raw material mixed with $\mathrm{NaOH}$ as an alkali activator. Results indicated that ground fly ash gave higher strength geopolymer compared to the original fly ash. Compressive strengths at 28 days of 20.023.0 MPa were obtained.

Investigations carried out by Kumar and Kumar [14] used mainly high energy density mills, such as vibratory and stirred media mill. It was revealed that beside the particle size distribution or the specific surface area the reactivity depended on the mill type used for the mechanical activation of the raw material. Sample with the same fineness activated in different type of mill resulted in different mechanical and structural properties of the geopolymer. The effect of mechanical activation of fly ash on geopolymers was investigated also by [14, 18, 19].

Sanytsky et al [35] investigated the effect of ground fly ash on concrete properties, the flowability of the concrete mix increases to $240 \mathrm{~mm}$ without strength loss by $114 \%$, the compressive strength is higher by $62 \%$, furthermore, it gives the possibility to reduce costs by reducing the cement content by $20 \%$.

Marjanovic et al [36] investigated mechanically activated FA in planetary ball mill. Geopolymerization was conducted by use of sodium silicate at $95{ }^{\circ} \mathrm{C}$ for 4 hours. It was observed that mechanical activation of FA for $15 \mathrm{~min}$ resulted in increase of geopolymer compressive strength (ten times higher).High strength values were associated with improved FA reactivity obtained mainly by the reduction in particle size and reduced water/binder ratio.

Another work [37] reported the results of mechanical activation of fly ash conducted in a planetary ball mill, while blends of fly ash and blast furnace slag were prepared with different ratios. Alkali activation was carried out at $95^{\circ} \mathrm{C}$ by use of sodium silicate solution as an activator. Significant increase of geopolymer strength was observed in respect to the geopolymer based on the initial fly ash. Optimal geopolymer strength was correlated with the chemical composition of the binding gel.

Mechanically activated fly ash can be utilized in geopolymer concrete as well. In a study [40] authors investigated the synergetic application of fly ash based geopolymer binder and steel making converter slag as aggregate. They established that the secondary raw materials were successfully applied collectively in the geopolymer concrete, thus creating a product for construction industrial purposes with a nearly 20 $\mathrm{MPa}$ compressive strength after 7 days.

Fig. 3 shows the relationship between compressive strength of geopolymer and the fineness of fly ash concerning two brown coals and one black coal from Hungary as raw materials of fly ash. It can be observed that the compressive strength is increased dramatically by 10 -times due to the mechanical treatment of fly ash. The geopolymerization of MA fly ash was carried out in alumina refinery liqueur at elevated temperature.

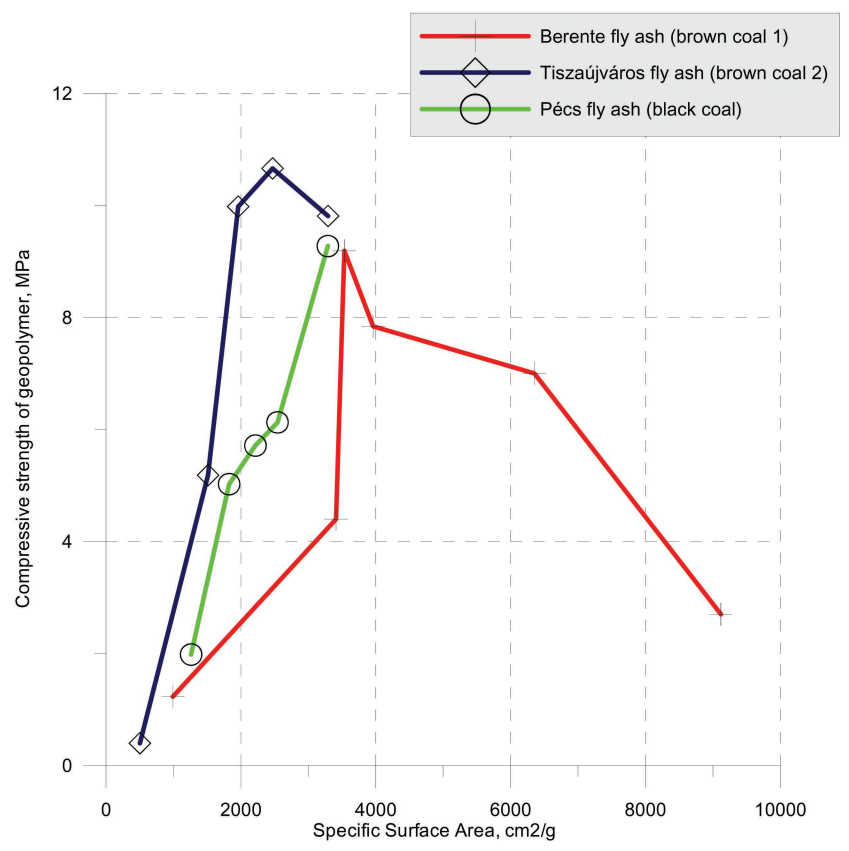

Fig. 3. Relationship between compressive strength of geopolymer (7 days) and fly ash fineness

3.ábra Geopolimer szilárdsága (7 napos korban) és pernye finomsága közötti kapcsolat

Mucsi et al [19] established relationship between the grinding process, the ground material properties and the geopolymer characteristics, i. e. strength of the specimen strongly depends on the grinding conditions, i.e. type of mill, grinding stresses and residence time. The variation of the uniformity factor of ground FA was investigated as well. It was demonstrated that fly ash with a much wider particle size distribution can be generated by stirred media mill which resulted in advantageous properties of the geopolymer products (e.g. ten times higher compressive strength).

Kumar et al developed geopolymer with $120 \mathrm{MPa}$ compressive strength by grinding of fly ash in vibratory mill [17].

Based on the reported data it can be concluded that most of the research work is based on material related investigations, however the product properties of raw materials are strongly depend on the mill types and parameters $[14,19]$. Therefore, the mechanical activation can be controlled consciously by using e.g. the stress model [41, 42, 43].

\section{Conclusions}

The fundamentals of mechanical activation of fly ash were presented in this paper based on a comprehensive literature review in terms of effects of mechanical treatment on the fly ash characteristics.

It is reported in most papers that due to the mechanical activation, beside the physical properties of fly ash (particle size distribution, specific surface area), the morphological and mineralocigal characteristics are varied as well, for example amorphisation takes place. 
These modified fly ash properties resulted in favourable effect on the performance of hydraulic binder and geopolymer (improved consistency, higher density and compressive strength).

Since the reactivity of fly ash can be tailored, the importance of the conscious control of the mechanical activation of fly ash by grinding parameters is highlighted.

\section{Acknowledgements}

This work was supported by the János Bolyai Research Scholarship of the Hungarian Academy of Sciences (MTA) and by the Hungarian Scientific Research Fund (OTKA) project entitled Durability and performance characteristics of concretes with novel types supplementary materials(project No.: OTKA K 109233).

The research work was performed in the Centre of Excellence in Sustainable Natural Resource Management at the Faculty of Earth Science and Engineering, University of Miskolc.

\section{References}

[1] Heidrich, C. - Feuerborn, J. J. - Weir, A. (2013): Coal Combustion Products: A Global Perspective. World of Coal Ash Conference. 2013 April 22-25

[2] Smekal, A. G. (1952): Proceedings of the International Symposium on the Reactivity of Solids (ed. Hedvall, J. A.). Cotenburg

[3] Juhász, A. Z. - Opoczky, L. (1990): Mechanical Activation of Minerals by Grinding. Akadémiai Kiadó - Ellis Horwood Ltd Publishers. Budapest Chichester

[4] Baláž, P. (2008): Mechanochemistry in Nanoscience and Minerals Engineering. Springer-Verlag, Berlin-Heidelberg, $413 \mathrm{p}$

[5] Boldyrev, V. V. - Pavlov, S. V. - Goldberg, E. L. (1996): Interrelation between fine grinding and mechanical activation. International Journal of Mineral Processing, Vol. 44-45, pp.181-185. http://dx.doi.org/10.1016/0301-7516(95)00028-3

[6] Baláž, P. - Achimovičová, M. - Baláž, M. - Billik, P. - Cherkezova-Zheleva, Z. - Criado, J. M. - Delogu, F. - Dutková, E. - Gaffet, E. - Gotor, F. H. Kumar, R. - Mitov, I. - Rojac, T. - Senna, M. - Streletskii, A. - WieczorekCiurowa, K. (2013): Hallmarks of mechanochemistry: from nanoparticles to technology. Chemical Society Reviews, Vol. 42, pp. 7571-7637. http://dx.doi.org/10.1039/C3CS35468G

[7] Hela, R. - Orsáková, D. (2013): The mechanical activation of fly ash. Procedia Engineering, Vol. 65, pp. 87-93. http://dx.doi.org/10.1016/j.proeng.2013.09.016

[8] Kumar, S. - Kristaly, F. - Mucsi, G. (2015): Geopolymerisation behavior of size fractioned fly ash. Advanced PowderTechnology, Vol. 26, No. 1, pp. 24-30. http://dx.doi.org/10.1016/j.apt.2014.09.001

[9] Bouzoubaa, N. - Zhang, M. H. - Bilodeau, A. - Malhotra V. M. (1997): The effect of grinding on the physical properties of fly ashes and a portland cement clinker. Cement and Concrete Research, Vol. 27, No. 12, pp. 18611874. http://dx.doi.org/10.1016/S0008-8846(97)00194-4

[10] Payá, J. - Monzó, M. - Borrachero, M. V. - Peris-Mora, E. (1996): Comparisons among magnetic and non-magnetic fly ash fractions: Strength development of cement-fly ash mortars. Waste Management, Vol. 16, No. 1-3, pp. 119-124 http://dx.doi.org/10.1016/S0956-053X(96)00034-7

[11] Opoczky, L. (1977): Fine grinding and agglomeration of silicates. Powder Technology, Vol. 17, pp. 1-7. http://dx.doi.org/10.1016/0032-5910(77)85037-7

[12] International Energy Agency - Coal Industry Advisory Board: The Impact of Global Coal Supply on Worldwide Electricity Prices, Overview and comparison between Europe, the United States, Australia, Japan, China and South Africa. 2014

[13] Mádai, F. - Kristály, F. - Mucsi, G. (2015): Microstructure, Mineralogy And Physical Properties of Ground Fly Ash Based Geopolymers. Ceramics -Silikáty, Vol. 59, No. 1, pp. 70-79.

http://www.ceramics-silikaty.cz/2015/pdf/2015_01_70.pdf
[14] Kumar, S. - Kumar, R. (2011): Mechanical activation of fly ash: Effect on reaction, structure and properties of resulting geopolymer. Ceramics International, Vol. 37, No. 2, pp. 533-541. http://dx.doi.org/10.1016/j.ceramint.2010.09.038

[15] Yeheyis, M. B. - Shang, J. Q. - Yanful, E. K. (2009): Chemical and Mineralogical Transformations of Coal Fly Ash after Landfilling. World of Coal Ash Conference (WOCA), May 4-7, 2009. Lexington, Kentucky, USA

[16] Kusnierová, M. - Slesárová, A. - Prascáková, M. (2005): The significance of fly ash for their processing and utilization. In. Proc. Waste Recycling IX. Krakow, 17-19. November 2005.

[17] Kumar, R. - Kumar, S. - Mehrotra, S. P. (2007): Towards sustainable solutions for fly ash through mechanical activation. Resources, Conservation and Recycling, Vol. 52, No. 2, pp. 157-179.

http://dx.doi.org/10.1016/j.resconrec.2007.06.007

[18] Temuujin, J. - Williams, R. P. - van Riessen, A. (2009): Effect of mechanical activation of fly ash on the properties of geopolymer cured at ambient temperature. Journal of Materials Processing Technology, Vol. 209, Issue 12-13, pp. 5276-5280.

http://dx.doi.org/10.1016/j.jmatprotec.2009.03.016

[19] Mucsi, G. - Kumar, S. - Csőke, B. - Kumar, R. - Molnár, Z. - Rácz, Á. Mádai, F. - Debreczeni, Á. (2015): Control of geopolymer properties by grinding of land filled fly ash. International Journal of Mineral Processing, Vol. 143, pp. $50-58$. http://dx.doi.org/10.1016/j.minpro.2015.08.010

[20] Mucsi, G. - Csőke, B. - Gál, A. - Szabó, M. (2009): Mechanical activation of lignite fly ash and brown coal fly ash and their use as constituents in binders: Mechanische Aktivierung von Lignit- und Braunkohlenflugasche und ihre Verwendungals Bindemittel. Cement International, Vol. 7, No. 4, pp. 76-85.

[21] Molnár, Z. - Kristály, F. - Mucsi, G. (2014): Mechanical Activation of Deposited Brown Coal Fly Ash in Stirred Media Mill. Acta Physica Polonica A, Vol. 126, No. 4. pp. 988-993. http://dx.doi.org/10.12693/APhysPolA.126.988

[22] Mucsi, G. - Lakatos, J. - Molnár, Z. - Szabó, R. (2014): Development of geopolymer using industrial waste materials. The 9 th International Conference “ENVIRONMENTAL ENGINEERING"22-23 May 2014, Vilnius, Lithuania http://dx.doi.org/10.3846/enviro.2014.039

[23] ASTM C618 (2012) Standard specification for coal fly ash and raw or calcined natural pozzolan for use in concrete.

[24] Terzić, A. - Andrić, L. - Miličić. L. - Radojević, Z. (2015): Energy transfer and conversion recorded on mechanically activated fly ash grains. International Journal of Modern Manufacturing Technologies ISSN 2067-3604, Vol. VII, No. 1

[25] Paul, K. T. - Satpathy, S. K. - Manna, I. - Chakraborty, K. K. - Nando, G. B. (2007): Preparation and Characterization of Nano structured Materials from Fly ash: A Waste from Thermal Power Stations, by High Energy Ball Milling. Nanoscale Research Letters, Vol. 2, pp. 397-404. http://dx.doi.org/10.1007/s11671-007-9074-4

[26] Xiaoru, F. - Qin, L. - Jianping Z. - Guanghong, S. - Feihu, L. (2008): The physical-chemical characterization of mechanically-treated CFBC fly ash. Cement and Concrete Composites, Vol. 30, pp. 220-226. http://dx.doi.org/10.1016/j.cemconcomp.2007.08.006

[27] Sharma, A. - Srivastava, K. - Devra, V. - Rani, A. (2012): Modification in Properties of Fly Ash through Mechanical and Chemical Activation. American Chemical Science Journal, Vol. 2, No. 4, pp. 177-187.

[28] Patil, G.A. - Anandhan, S. (2012): Ball Milling of Class-F Indian Fly Ash obtained from a Thermal power Station. International Journal of Energy Engineering, Vol. 2, pp. 57-62.

[29] Rao, J. - Narayanaswami, P. - Prasad, K. S. (2010): Thermal stability of nano structured fly ash synthesized by high energy ball milling. International Journal of Engineering, Science and Technology, Vol. 2, No.5, pp. 284-299. http://dx.doi.org/10.4314/ijest.v2i5.62577

[30] Sharma, A. - Kabra, S. - Katara, S. - Rani, A. (2015): Variation of Surface Morphology and Physico-Chemical Properties of the Fly Ash Through Mechanical and Thermal Activations. Journal of Advanced Chemical Sciences, Vol. 1, No. 2, pp. 70-74.

[31] Patil, A. G. - Anandhan, S. (2015): Influence of planetary ball milling parameters on the mechano-chemical activation of fly ash. Powder Technology, Vol. 281, pp. 151-158.

http://dx.doi.org/10.1016/j.powtec.2015.04.078 
[32] Davis, R. E. - Carlston, R. W. - Kelly, J. W. - Davis, H. E. (1937): Properties of cements and concretes containing fly ash. ACI Journal, Vol. 33, No. 5, pp. 577-612. http://dx.doi.org/10.14359/8435

[33] Davidovits, J. (1989): Geopolymers and geopolymeric materials. Journal of Thermal Analysis, Vol. 35, No. 2, pp. 429-441. http://dx.doi.org/10.1007/BF01904446

[34] Somna, K. - Jaturapitakkul, C. - Kajitvichyanukul, P. - Chindaprasirt, P. (2011): $\mathrm{NaOH}$-activated ground fly ash geopolymer cured at ambient temperature. Fuel, Vol. 90, No. 6, pp. 2118-2124. http://dx.doi.org/10.1016/j.fuel.2011.01.018

[35] Sanytsky, M. - Rusyn, B. - Halbiniak, J. - Szymańska, J. (2013): Influence of ultrafine ground fly ash on the microstructure and properties of cementitious materials. Budownictwo o zoptymalizowanym potencjale energetycznym, Vol. 2, No. 12, pp. 96-102

[36] Marjanović, N. - Komljenović, M. - Baščarević, Z. - Nikolić, V. (2014): Improving reactivity of fly ash and properties of ensuing geopolymers through mechanical activation. Construction and Building Materials, Vol. 57, pp. 151-162. http://dx.doi.org/10.1016/j.conbuildmat.2014.01.095

[37] Marjanović, N. - Komljenović, M. - Baščarević, Z. - Nikolić, V. (2015): Comparison of two alkali-activated systems: mechanically activated fly ash and fly ash-blastfurnace slag blends. Procedia Engineering, Vol. 108, pp. 231 - 238. http://dx.doi.org/10.1016/j.proeng.2015.06.142

[38] Blanco, F. - Garcia, M. P. - Ayala, J. (2005): Variation in fly ash properties with milling and acid leaching. Fuel, Vol. 84, pp. 89-96 http://dx.doi.org/10.1016/j.fuel.2004.05.010

[39] Juhász A. Z. - Opoczky L. (2003): Mechanokémia és agglomeráció, Építőanyag, Vol. 55, No. 3, pp. 86-90. http://dx.doi.org/10.14382/epitoanyag-jsbcm.2003.16

[40] Mucsi, G. - Rácz, Á. - Molnár, Z. - Szabó, R. - Gombkötő, I. - Debreczeni, Á. (2014): Synergetic use of lignite fly ash and metallurgical converter slag in geopolymer concrete. Mining Science, Vol. 21, pp. 43-55. http://dx.doi.org/10.5277/ms142104

[41] Kwade, A. (2004): Mill selection and process optimization using a physical grinding model. International Journal of Mineral Processing, Vol. 74, S93-S101. http://dx.doi.org/10.1016/j.minpro.2004.07.027

[42] Rácz, Á. (2014): Reduction of Surface Roughness and Rounding of Limestone Particles in Stirred Media Mill. Chemical Engineering ↔Technology, Vol. 37, No. 5, pp. 865-872. http://dx.doi.org/10.1002/ceat.201300671
[43] Mucsi, G. - Rácz, Á. - Mádai, V. (2013): Mechanical activation of cement in stirred media mill. Powder Technology, Vol. 235, pp. 163-172. http://dx.doi.org/10.1016/j.powtec.2012.10.005

[44] Faitli J. - Gombkötő, I. (2015): Some technical aspects of the rheological properties of high concentration fine suspensions to avoid environmental disasters. Journal of Environmental Engineering and Landscape Management, Vol. 23, No. 2, pp. 129-137.

http://dx.doi.org/10.3846/16486897.2015.1021698

[45] Gável Viktória - Opoczky Ludmilla (2004): A szemcseméret-eloszlás jelentősége pernyeadalékos cementek előállításánál. Épitőanyag Vol. 56, Issue 4 pp. 130-133. http://dx.doi.org/10.14382/epitoanyag-jsbcm.2004.15

$\underline{\text { Ref.: }}$

Mucsi, Gábor: Mechanical activation of power station fly ash by grinding - A review

Építőanyag - Journal of Silicate Based and Composite Materials, Vol. 68, No. 2 (2016), 56-61. p http://dx.doi.org/10.14382/epitoanyag-jsbcm.2016.10

\section{Erőműi pernye mechanikai aktiválása őrléssel - áttekintés}

Az erômúi pernye relatíve jó alkalmazási lehetôségekkel rendelkezik, elsősorban az építőipar területén. Ennek ellenére jelentôs mennyiségben kerül lerakásra az alacsony reaktivitása és nagy heterogenitása miatt. A hidraulikus tulajdonságai azonban mechanikai aktiválással javíthatóak, ami egy nagyobb hozzáadott értékú terméket fog eredményezni, például cement kiegészítô anyagot. Ezen megváltozott jellemzôk, úgymint nagyobb fajlagos felület, kívánt szemcseméret eloszlás (amely szubmikronos szemcséket is tartalmaz), nagyobb reaktivitású alkotók, ôrléssel optimálisan szabályozhatóak. Jelen cikk tárgya, a mechanikai aktiválás erômúi pernye fizikai-kémiai és ásványtani tulajdonságaira gyakorolt hatásának vizsgálata. Megállapítható, hogy számos megoldás létezik a pernye mechanika aktiválására, úgymint planétamalom, vibrációs malom, vagy keverố golyósmalom. Az eredmények többsége azonban anyagközpontú kutatásokra fókuszál, holott, energetikai szempontból az eljárásközpontú értékelést is számításba kellene venni. Kulcsszavak: mechanikai aktiválás, ôrlés, erőmúi pernye, reaktivitás, energiahatékonyság.

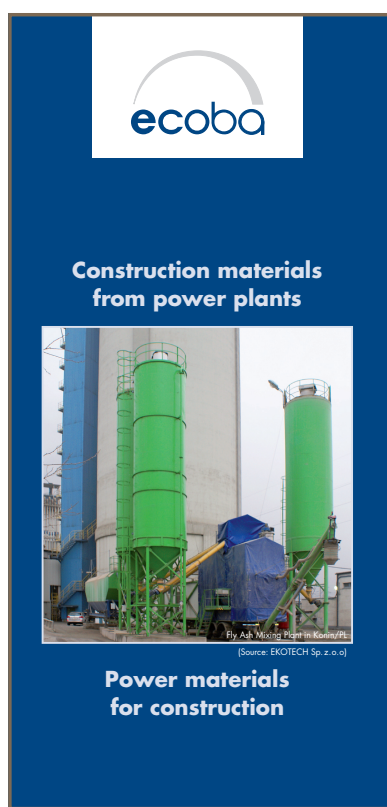

ECOBA was founded in 1990 by European energy producers to deal with matters related to the usage of construction raw materials from coal. The initial membership consisted of 10 companies and associations from across Europe, all generators of electricity and heat. Since then more companies have been elected as members giving the association 24 full members from 15 countries across Europe.

ECOBA members represent over $86 \%$ of the CCP production in the EU 28 countries. ECOBA has associations with other international institutions providing a vast network of contacts and experience. ECOBA has been particularly active in the development of European standards and is represented on a number of CEN committees.

\section{Mission}

ECOBA members consider coal combustion products (CCPS), that are combustion residues and desulphurisation products generated in coal-fired power plants, to be valuable raw and construction materials which can be utilized in various environmentally compatible ways. It is the task of ECOBA to propagate this message especially amongst legislative and standardising institutions and to communicate the economic and ecological benefits of CCP utilisation.

\section{The mission of ECOBA is}

- to encourage the development of the technology for the use of all by-products from coal-fired power stations, both on the industrial and the environmental level, with regard to relevant industrial and environmental demands;

- to promote the mutual interests of its members, internationally and particularly within the framework of the European organisations, which are of scientific, technical, ecological and legal nature;

- to establish and/or develop necessary legal/regulatory measures for recognition, acceptance and promotion of the use of all by-products of coal-fired power stations as valuable recoverable resources;

- to participate in international activities, induding co-operation within the framework of the European organisations, and

- to ensure the exchange of information and documentation among the various national and international bodies.

In order to accomplish these aims, ECOBA maintains and develops close links with all parties interested in the earth's resources - from governments to end users and in construction.

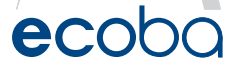

European Coal Combustion Products Association e.V. Office: VGB PowerTech · Deilbachtal 173 - D-45257 Essen Phon +49-201-8128-274 - Fax +49-201-8128-364 E-mail: info@ecoba.org ·www.ecoba.org 